Oregon Undergraduate Research Journal

5.1 (2013) ISSN: 2160-617X (online)

http:// journals.oregondigital.org/ourj/

DOI: 10.5399/uo/ourj.5.1.3366

(c) $\underset{\mathrm{EY}}{(\mathrm{P}}$

\title{
Welcome
}

\section{Zeph Schafer*}

Welcome to the fifth installment of the Oregon Undergraduate Research Journal! This issue marks the second anniversary of our first publication. Students started this journal to honor and encourage research beyond the "term-by-term grind" of classes. Now, for two years OURJ has continued to publish undergraduate research in order to share outstanding work with the university community and to provide inspiration for student peers.

In this issue, we are excited to publish four articles in the disciplines of Economics, Environmental Science, English and Biology. In "Apartment Price Models for the Glenwood Riverfront Development," Joseph Friedman employs Hedonic price modeling to assess studenthousing prices near the University of Oregon. His research presents recommendations for developers and governments involved in a proposed development in nearby Springfield. In "Prey Detection and Feeding Success of the Comb Jellyfish Mnemiopsis leiydi on Copepods in Still and Turbulent Waters," Clare Chisholm investigates the effects of water turbulence on the feeding behavior of the M. leiydi jellyfish. Chelsea Arsenault's “The Virgin Knight: Spenser's Embodiment of Duality in Elizabethan England" investigates gender dynamics within the poetry of sixteenth-century English author Edmund Spenser. Finally, in "Bioremediation Mariculture in Zanzibar, Tanzania: A viability assessment of using bath sponge and pearly oyster farms to filter highly polluted waters in the Zanzibar Channel," Hayley Oakland investigates the ability of marine organisms to self-restore their environment after pollution.

The publication of this journal depends on the support of many dedicated individuals. Our editorial board, Charlotte, Lauren, Mari, Sage, Laura, Janelle, Jessica and Biraj devote their time throughout the year to finding and publishing high-quality research. I greatly appreciate their commitment. Our faculty advisors, Dr. Barbara Jenkins and Dr. Kevin Hatfield, provide invaluable advice and guidance on the development of the journal. Finally, this issue would not have been published without the technical support provided by the University of Oregon Libraries, and especially John Russell and Cat Bradley. Thank you! 